Meta

Journal des traducteurs

Translators' Journal

\title{
The Use of Transformations in Translating News Reports from English into Arabic
}

\section{Hala Sharkas}

Volume 60, numéro 2, août 2015

$60^{\mathrm{e}}$ anniversaire. Les horizons de la traduction : retour vers le futur $60^{\text {th }}$ Anniversary. Translation's Horizons: Back to the Future

60mo aniversario. Los horizontes de la traducción: regreso al futuro

URI : https://id.erudit.org/iderudit/1032921ar

DOI : https://doi.org/10.7202/1032921ar

Aller au sommaire du numéro

Éditeur(s)

Les Presses de l’Université de Montréal

ISSN

0026-0452 (imprimé)

1492-1421 (numérique)

Découvrir la revue

Citer ce document

Sharkas, H. (2015). The Use of Transformations in Translating News Reports from English into Arabic. Meta, 60(2), 370-370.

https://doi.org/10.7202/1032921ar d'utilisation que vous pouvez consulter en ligne. 


\title{
The Use of Transformations in Translating News Reports from English into Arabic
}

\author{
Hala Sharkas \\ United Arab Emirates University, Al Ain, United Arab Emirates \\ hala_sharkas@yahoo.com
}

According to Schäffner, news translation is "a textual and sociocultural process which involves transformations" (Schäffner 2012: 881). Such transformations include mainly reorganization, deletion, addition, and substitution (Hursti 2001). They are used not only as part of the translation process, but also as part of the process of gatekeeping, which is defined as "the process of controlling the flow of information into and through communication channels" (Vuorinen 1995: 161).. Beyond the ideology and censorship which may influence the process of gatekeeping and which differ from one news provider to another, there are other factors related to culture, topic, medium and audience, which can affect the choice of transformations in news translating.

The aim of this paper is to examine these factors and identify the type of content or information with which such transformations are used. The importance of the findings of this research lies not only in shedding more light on the role that translation plays in the complex process of news production, but also in helping to improve the teaching of journalistic translation. Identifying relational patterns between content and the transformations used in professional settings of journalistic translation will allow for more realistic classroom translation tasks.

To achieve this aim, a corpus of 40 Arabic translations of English news reports is analyzed to identify the transformations applied in each text and the information subjected to these transformations. Half the texts in the corpus are audiovisual news stories translated by an Arabic TV station, while the other half is made of written news reports provided on the website of an international news agency. Results are compared to find any common patterns of transformations and type of content especially in light of the differences in news provider and medium.

Hala Sharkas is Assistant Professor of Translation at the Department of Translation Studies of the United Arab Emirates University. Her research areas are mainly scientific and technical translation, translation quality assessment, translation teaching and recently news translation. Before joining academia, she worked as a professional translator for several years in the public and private sectors, and as a freelancer; she is also a sworn translator. She is a member of the Executive Board of IATIS (the International Association of Translation and Intercultural Studies). 